\title{
PENGARUH TEKANAN WAKTU, INDEPENDENSI DAN ETIKA AUDITOR TERHADAP KUALITAS AUDIT DI KANTOR INSPEKTORAT KABUPATEN KEPULAUAN SANGIHE
}

\author{
Julita Pikirang $^{1}$, Harijanto Sabijono ${ }^{2}$, Heince R.N Wokas ${ }^{3}$ \\ 1,2,3 Jurusan Akuntansi, Fakultas Ekonomi dan Bisnis, Universitas Sam Ratulangi, Jl. Kampus Bahu, Manado, \\ 95115, Indonesia \\ E-mail: julitaapikirang@gmail.com
}

\begin{abstract}
This study aims to analyze the influence of time pressure, independence and auditor ethics on audit quality in Inspectorate Office of Sangihe Islands Regency. Data collection method used is with questionnaire technique with respondents who work in Inspectorate of Sangihe Islands Regency. Responspondents in this study amounted to 35. Data analysis techniques used were to use data quality test, classical assumption test and hypothesis test. Test the quality of data used is the test of validity and reliability test. The classical assumption test used in this research is normality test, multicolonierity test, and heteroscedasticity test. Hypothesis test used is multiple linear regression test and t test. The result of this research is time pressure and independence has no significant effect on audit quality while ethics has significant effect to audit quality. This means that the biggest influence on audit quality is ethics.
\end{abstract}

\section{Keywords: Time Pressure, Independence, Ethics and Audit Quality}

\section{PENDAHULUAN}

Tuntutan dimasa demokrasi seperti saat ini, pemerintah dituntut untuk semakin efektif, efesien, transparan, akuntabel serta bersih dan bebas dari praktik korupsi, kolusi, dan nepotisme terhadap pengelolaan dana keuangan negara. Pemerintah yang berkompeten dalam menjalankan tugas sebagai fungsi pengawasan intern yang andal dan sistem pengendalian intern yang baik untuk pertanggungjawaban atas penggunaan dana untuk pelaksanaan pemerintahan yang menjamin pelaksanaan kegiatan dapat merata keseluruh sektor publik serta telah sesuai dengan kebijakan dan rencana yang ditetapkan dan ketentuan yang berlaku.Inspektorat sebagai internal audit pemerintah dam merupakan sumber informasi yang penting bagi auditor eksternal (BPK) dan menjadi ujung tombak untuk meningkatkan transparansi dan akuntabilitas dalam pengelolaan keuangan daerah, karena hasil audit yang berkualitas merupakan sumber informasi penting dalam memberikan keyakinan kepada pihak pemerintah, DPRD dan BPK. Pengelolaan keuangan pemerintah yang baik harus didukung audit sektor publik yang berkualitas, jika kualitas audit sektor publik rendah, kemungkinan memberikan kelonggaran terhadap lembaga pemerintah melakukan penyimpangan penggunaan anggaran. Selain itu juga mengakibatkan risiko tuntutan hukum terhadap aparatur pemerintah yang melaksanakannya (Atmawinata,2014).

Dalam kegiatan audit, banyak auditor menghadapi kendala tentang batasan waktu yang sering diberikan untuk membuat laporan dengan waktu yang singkat.Adanya batasan waktu tersebut, auditor mersa adanya tekanan waktu dalam menemukan temuan audit sebagai bukti laporan audit. Tekanan waktu dapat menyebabkan penurunan kualitas audit, karena adanya time budgetpressure dan time deadline pressure. Time budget pressure digunakan untuk menuntut auditor melakukan efesiensi waktu terhadap anggaran waktu yang telah disusun, hal ini terkait adanya pembatasan waktu.Time deadlinepressure berkaitan dengan kondisi dimana seorang auditor dituntut untuk menyelesaikan tugas audit tepat pada waktunya (Putra, 2012). 
Independensi merupakan sikap yang bebas dari pengaruh pihak lain secara inetelektual, jujur dan objektif dalam mempertimbangkan fakta dan opininya. Sikap independen sangat dibutuhkan oleh seorang auditor dalam memberikan jasa audit yang disediakan untuk para pemakai laporan keuangan. Selain itu independensi auditor juga merupakan salah satu faktor yang sangat penting untuk menilai kualitas audit yang dihasilkan (Saputra, 2012). Etika auditor merupakan prinsip moral yang harus dijadikan pedoman ketika seorang auditor melakukan audit agar menghasilkan audit yang berkualitas. Itu sebabnya setiap auditor diharapkan memegang teguh etikan profesi yang sudah ditetapkan Ikatan Akuntansi Indonesia (IAI), agar situasi persaingan tidak sehat dapat dihindarkan. Etika akuntan menjadi isu yang sangat menarik. Hal ini sering terjadinya beberapa pelanggaran etika yang dilakukan akuntan baik akuntan independen, akuntan itern, maupun akuntan pemerintah. Kualitas audit yang baik pada prinsipnya dapat dicapai jika menerapkan standarstandar dan prinsip-prinsip audit, bersikap bebas tak memihak,patuh kepada hukum, serta mentaati kode etik profesi. Standar Profesional Akuntan Publik (SPAP) adalah pedoman yang mengatur standar umum pemeriksaan akuntan publik, mengatur segala hal yang berhubungan dengan penugasan, Indpendensi dalam sikap mental.

Berdasarkan latar belakang masalah, maka rumusan masalah dalam penelitian ini adalah : (1) apakah tekanan waktu berpengaruh signifikan terhadap kualitas audit?; (2) apakah independensi berpengaruh signifikan terhadap kualitas audit; (3) apakah etika berpengaruh signifikan terhadap kualitas audit? Adapun tujuan yang ingin dicapai dalam penelitian ini adalah : (1) untuk mengetahui pengaruh tekanan waktu auditor terhadap kualitas audit pada Kantor Inspektorat Kabuaten Kepulauan Sangihe; (2) untuk mengetahui pengaruh Independensi auditor terhadap kualitas audit pada Kantor InspektoratKabuaten Kepulauan Sangihe; (3) untuk mengetahui pengaruh Etika auditor terhadap kualitas audit pada Kantor InspektoratKabuaten Kepulauan Sangihe.

\section{TINJAUAN PUSTAKA}

\subsection{Akuntansi}

Akuntansi adalah pengukuran, penjabaran, atau pemberian kepastian mengenai informasi yang akan membantu manajer, investor, otoritas pajak dan pembuat keputusan lain untuk membuat alokasi sumber daya keputusan di dalam perusahaan, organisasi, dan lembaga pemerintah. Secara umum, akuntansi dapat didefinisikan sebagai informasi yang memberikan laporan kepada pengguna informasi akuntansi atau kepada pihak-pihak yang memiliki kepentingan (stakeholder) terhadap hasil kinerja dan kondisi keuangan perusahaan (Hery, 2014:1). Akuntansi dapat didefinisikan sebagai suatu sistem informasi yang menyediakan laporan-laporan kepada para pihak yang berkepentingan mengenai aktivitas ekonomi dan kondisi suatu perusahaan (Warren dan Jonathan, 2017:6).

\subsection{Akuntansi Pemerintah}

Ada beberapa pengertian akuntansi pemerintahan yang telah dikemukakan antara lain sebagai berikut :

1. Deddi, dkk (2012:4) akuntansi pemerintahan mengkhususkan dalam pencatatan dan pelaporan transaksi yang terjadi di badan pemerintah. Akuntan pemerintah menyediakan laporan akuntansi tentang aspek kepengurusan dari administrasi keuangan negara.

2. Halim (2008:35) akuntansi keuangan daerah adalah "proses pengidentifikasian, pengukuran, pencatatan, dan pelaporan transaksi ekonomi (keuangan) dari entitas pemerintah daerah (kabupaten, kota atau provinsi) yang dijadikan informasi dalam rangka pengambilan keputusan ekonomi oleh pihak-pihak eksternal pemerintah daerah yang memerlukan". 


\subsection{KonsepAuditor}

\subsubsection{Pengertian Auditor}

Audit adalah jasa yang diberikan oleh auditor dalam memeriksa dan mengevaluasi laporan keuangan yang disajikan oleh perusahaan klien. Pemeriksa ini tidak dimaksudkan untuk mencari-cari kesalahan atau menemukan kecurangan, walaupun dalam pelaksanaanya sangat memungkinkan ditemukan kesalahan atau kecurangan. Pemeriksaan atas laporan keuangan dimaksudkan untuk menilai kewajaran laporan keuangan, berdasarkan prinsip akuntansi yang berlaku (Bustami, 2013).

Ditinjau dari pemeriksa (auditor) yang melaksanakan audit, pada dasarnya audit dapat digolongkan menjadi dua jenis yaitu audit pihak dalam (audit internal) dan audit pihak luar.Audit internal adalah kegiatan penilaian independen yang dibentuk dalam suatu organisasi untuk memeberikan jasa kepada pihak manajemen dalam bentuk penelahan kegiatan organisasi. Audit internal merupakan pengendalian manajerial yang fungsinya mengukur dan mengevaluasi keefektifan system pengendalian lain. Sedangkan audit eksternal adalah suatu proses audit yang sistematik dan obyektif terhadap laporan keuangan dengan tujuan untuk memberikan pendapat mengenai kewajaran keadaan keuangan (Tandiontong, 2015:67).

\subsubsection{Tujuan Audit}

Tujuan adalah untuk menyatakan pendapat atas kewajaran, dalam semua hal yang material, posisi keuangan sesuai dengan prinsip akuntansi yang berlaku umum. Tujuan audit spesifik ditentukan berdasarkan asersi-asersi yang dibuat oleh manajemen yang tercantum dalam laporan keuangan. Asersi manajemen adalah pernyataan yang dinyatakan dengan jelas oleh manajemen mengenai jenis transaksi dan akun terkait dalam laporan keuangan. Asersi manajemen berhubungan langsung dengan prinsip akuntansi yang berlaku umum, sehingga auditor harus memahami asersi-asersi manajemen agar audit dapat dilaksanakan dengan memadai (Nur Aini, 2012).

\subsubsection{Jenis Audit}

Menurut Halim (2015), Ada 3 jenis-jenis audit, yaitu:

1. Audit Laporan Keuangan

Audit laporan keuangan bertujuan untuk menetukan apakah laporan keuangan secara keseluruhan telah disajikan sesuai dengan kriteria-kriteria tertentu, kriteria ini adalah prinsip akuntansi yang berlaku umum.

2. Audit Operasional

Audit oprasional merupakan penelaan atas bagian manapun dari prosedur atau metode operasi suatu organisasi atau menilai efesiensi dan efektifitasnya.

3. Audit Ketaatan

Audit Ketaatan bertujuan untuk mempertimbangkan apakah klien telah mengikuti prosedur atau aturan tertentu yang telah ditetapkan pihak yang memiliki otoritas lebih tinggi.

\subsection{Konsep Audit Internal}

\subsubsection{Peranan Audit Internal}

Audit internal mempunyai peranan yang sangat penting dalam mencapai tujuan perusahaan yang telah ditentukan. Perlunya konsep audit internal dikarenakan bertambah luasnya ruang lingkup perusahaan. Oleh karena itu semakin besar suatu perusahaan, maka semakin luas pula rentang pengendalian yang dipakai pimpinan, sehingga menejemen harus menciptakan suatu pengendalian intern yang efektif untuk mencapai suatu pengelolaan yang optimal dengan memprtimbangkan manfaat dan biayanya. Karena keterbatasan manajemen 
dalam mengendalika aktivitasnya itu, perusahaan memerlukan audit internal yang akan membantu manajemen dalam menentukan apakah rencana-rencana operasi, keuangan, kebijakan dan prosedur-prosedur, yang dijalankan sesuai dengan ketentuan yang ada (Amalia, 2014).

\subsubsection{Pengertian Audit Internal}

Dalam standar professional audit internal disebutkan bahwa fungsi pemeriksaan intern adalah untuk meyakinkan keandalan informasi, keseuaian dengan kebijaksanaan, rencana, prosedur dan peraturan perundang-undangan, perlindungan terhadap asset, penggunaan sumber daya secara ekonomis dan efesien, dan pencapaian tujuan.

\subsection{Konsep Auditor}

Auditor adalah seorang independen dan kompeten yang melaksanakan audit. Audit adalah proses sistematis untuk secara objektif mendapatkan dan megengevaluasi bukti mengenai asersi tentang kegiatan-kegiatan dan kejadian-kejadian ekonomi untuk meyakinkan tingkat keterkaitan antara asersi tesebut dan kriteria yang telah ditetapkan dan mengkomunikasikan hasilnya kepada pihak-pihak yang berkepntingan. Dalam hal ini terdiri dari auditor yang bekerja pada Kantor Akuntan Publik (KAP) sesuai dengan Peraturan Menteri Keuangan No.17/ PMK.01/2008 dan auditor yang bekerja pada Badan Pemeriksa Keuangan (BPK) sesuai dengan Undang-Undang No, 16 Tahun 2006.

\subsection{Kualitas Audit}

Audit dikatakan berkualitas jika memenuhi standar yang seragam dan konsisten, yang menggamabarkan praktik-praktik terbaik audit internal serta merupakan ukuran kualitas dalam pelaksanaan tugas untuk memenuhi tanggung jawab profesinya. Standar tersebut dalam Standar Profesi Audit Internal (Setiadi, 2016). Menurut Tandiontong, (2016:80) kualitas audit didefenisikan sebagai berikut: Kualitas audit adalah segala probabilitas seorang auditor dalam menetukan dan melaporkan penyelewangan yang terjadi dalam sistem akuntansi klien atau perusahaan.Kualitas audit adalah kombinasi probabilitas dari auditor yang kompeten untuk menemukan pelanggaran dalam sistem akuntansi klien dan melaporkan temuan mereka secara tidak langsung.

\subsection{Tekanan Waktu}

Waktu yang diberikan oleh klien merupakan salah satu faktor yang mempengaruhi kualitas audit. Tekanan waktu didefenisikan sebagai kendala yang terjadi pada perikatan audit karena keterbatasan sumber daya berupa waktu yang dialokasikan untuk melaksanakan seluruh tugas audit. Tekanan waktu menyebabkan timbulnya stress akibat tidak seimbangnya tugas dan waktu yang tersedia serta mempengaruhi etika auditor (Fonda, 2014).

Tekanan waktu mempunyai dua dimensi yaitu:

1. Time Budget Pressuremerupakan keadaan dimana auditor dituntut untuk melakukan efesiensi terhadap anggaran waktu yang telah disusun, atau terdapat pembatasan waktu dalam anggaran yang sangat ketat.

2. Time Deadline Pressure merupakan kondisi dimana auditor dituntut untuk menyelesaikan tugas audit tepat pada waktunya.

\subsection{Independensi}

Independensi merupakan suatu cerminan sikap dari seorang auditor untuk tidak memilih pihak siapapun dalam melakukan audit. Independensi adalah sikap mental seorang auditor dimana ia dituntut untuk bersikap jujur dan tidak memihak sepanjang pelaksaan audit dan dalam memposisikan dirinya dengan auditee-nya (Suputra, 2013). Independensi auditor 
dapat terganggu oleh masa kerja auditor. Karena hubungan klien auditor semakin panjang, auditor dapat mengembangkan hubungan dekat dengan klien dan cenderung bertindak sesuai dengan manajemen, mempertimbangkan kembali objektivitas dan kualitas audit yang rendah (Tobi dan Emmanuel, 2016).

\subsection{Etika}

Etika adalah suatu prinsip moral dan perbuatan yang menjadi landasan bertindaknya seseorang sehingga apa yang dilakukannya dipandang oleh masyarakat sebagai perbuatan yang terpuji dan meningkatkan martabat dan kehormatan seseorang (Putra, 2012).

Seorang auditor dapat dikatakan professional apabila dalam menjalankan tugas-tugasnya harus sudah sesuai dengan aturan atau pedoman-pedoman Kode Etik Akuntan Indonesia, sehingga dalam melaksanakan semua aktivitasnya mempunyai arah yang jelas dan dapat memberikan keputusan yang tepat dan bias dipertanggungjawabkan kepada pihak-pihak yang menggunakan keputusan tersebut.

\section{METODE PENELITIAN}

\subsection{Jenis Data}

Jenis penelitian yang digunakan adalah kuantitatif dengan metode peneltian asosiatif dengan pola hubungan yaitu hubungan kausal. Menurut (Sugiyono, 2016:62) hubungan kausal adalah hubungan yang bersifat sebab akibat. Pendekatan yang digunakan dalam penelitian ini adalah pendekatan kuantitatif, yang bertujuan untuk menguji keandalan waktu atau teori yang kemudian akan menghasilkan kesimpulan-kesimpulan.

\subsection{Tempat dan Waktu Penelitian}

Penelitian dilakukan di Kantor Inspektorat Kabupaten Kepulauan Sangihe. Waktu penelitian dilaksanakan mulai dari bulan Mei sampai selesai.

\subsection{Prosedur Penelitian}

Adapun penelitian skripsi ini menggunakan tahap penelitian yang berhubungan dengan masalah yang diteliti. Tahap-tahapan tersebut adalah sebagai berikut:

1. Merumuskan masalah penelitian.

2. Melakukan telaah terhadap teori-teori yang berhubungan dengan masalah yang diteliti.

3. Merancang metodologi penelitian dan teknik pengumpulan data.

4. Memberikan kuesioner kepada auditor di Kantor Inspektorat Kabupaten Kepulauan Sangihe.

5. Melakukan analisis data yang telah diperoleh.

6. Memberikan kesimpulan yang logis berdasarkan hasil penelitian tersebut dan memberikan saran-saran dari hasil penelitian.

\subsection{Populasi dan Sampel}

\subsubsection{Populasi}

Menurut Furchan (dalam Taniredja dan Mustadifah, 2014:33) populasi dirumuskan sebagai "semua anggota sekelompok orang kejadian atau obyek yang telah dirumuskan secara jelas". Populasi dalam penelitian ini adalah auditor yang ada di Kantor Inspektorat Kabupaten Kepulauan Sangihe. Adapun populasi dalam penelitian ini adalah 40 orang.

\subsubsection{Sampel}

Sampel adalah bagian dari jumlah karakteristik yang dimiliki oleh populasi tersebut (Sugiyono 2016:120). Metode pengambilan sampel dilakukan dengan purposive sampling, 
metode ini merupakan teknik pengambilan sampel berdasarkan kriteria tertentu atau dengan pertimbangan terntentu. Teknik ini merupakan salah satu teknik Nonprobability Sampling dimana teknik pengambilan sampel yang tidak memberi peluang/kesempatan sama bagi setiap unsur atau anggota populasi untuk dipilih menjadi sampel (Sugiyono, 2016:125). Sampel dalam penelitian ini adalah 35 auditor di Kantor Inspektorat Kabupaten Kepulauan Sangihe.

\subsection{Metode Pengumpulan Data}

\subsubsection{Jenis Data}

Menurut Sugiyono (2013:13) dalam penelitian ada dua jenis data yang digunakan yaitu data kualitatif dan data kuantitatif.

1. Data Kualitatif adalah data yang digunakan untuk meneliti pada kondisi objek alamiah, dimana peneliti adalah sebagai instrument kunci,pengambilan sampel sumber data dilakukan secara purposive, teknik pengumpulan dengan trianggulasi, analisis data bersifat induktif/kualitatif, dan hasil penelitian kualitatif lebih menekankan makna dari pada generalisasi.

2. Data Kuantitatif, dapat diartikan sebagai metode penelitian yang berlandaskan pada filsafat positif, digunakan untuk meneliti pada populasi atau sampel terntentu, teknik pengambilan sampel pada umumnya dilakukan secara acak. Pengumpulan data menggunakan instrument penelitian, analisi data bersifat kuantitatif/statistic dengan tujuan untuk menguji hipotesis yang telah ditetapkan.

\subsubsection{Sumber Data}

Data merupakan penggambaran variabel yang diteliti dan berfungsi sebagi alat pembuktian hipotesis (Taniredja \& Mustadifah, 2014:41). Sumber data di dalam penelitian ini adalah data primer. Sumber data primer dalam penelitian ini adalah diperoleh langsung dari Inspektorat Kabupaten Kepulauan Sangihe. Data ini berupa kuesioner yang telah diisi oleh para auditor yang menjadi responden terpilih dalam penelitian ini.

\subsection{Teknik Pengumpulan Data}

Data yang digunakan dalam penelitian ini yaitu data primer. Data primer merupakan sumber data penelitian yang diperoleh secara langsung dari sumber asli atau tidak melalui perantara (Rosaldi, 2012).

Metode yang digunakan untuk mengumpulkan data dalam penelitian ini adalah metode survey. Teknik yang digunakan yaitu dengan menyebar kuesioner kepada auditor yang bekerja di Kantor Inspektorat Kab. Kepulauan Sangihe. Kuesioner merupakan teknik pengumpulan data yang dilakukan dengan cara memberi seperangkat pertanyaan atau pernyataan tertulis kepada responden untuk dijawab (Sugiyono, 2013:142). Kuesioner yang diberikan berisi pernyataan-pernyataan berkaitan dengan objek yang diteliti dan petunjuk pengisiannya. Kuesioner dilengkapi dengan surat izin dan penjelasan terkait tujuan dilakukannya penelitian tersebut.

\subsection{Metode Analisis}

Metode analisis data yang digunakan dalam penelitian ini adalah analisis regresi linear berganda uji statistik yang digunakan untuk menjalankannya. Metode analisis dilakukan dengan bantuan software Statistic Program Service Solution (SPSS) versi 17 untuk Windows, yaitu program computer yang khusus dibuat untuk mengelolah data secara statistik. 


\subsubsection{Analisis Regresi Linear Berganda}

Analisis regresi linear berganda merupakan suatu metode statistik umum yang digunakan untuk meneliti hubungan antara variabel dependen dengan beberapa variabel independen dan menggunakan nilai-nilai variabel independen yang telah diketahui untuk meramalkan nilai variabel dependen. Persamaan dari regresi linear berganda adalah sebagai berikut :

$$
Y=a+b_{1} X_{1}+b_{2} X_{2}+b_{3} X_{3}+e
$$

\subsubsection{Uji Kualitas Data}

Uji kualitas data dilakukan untuk mengetahui validitas dan konsistensi instrument yang digunakan dalam penelitian. Uji kualitas data berupa uji validitas dan uji reliabilitas.

1. Uji Validitas

Pengujian validitas digunakan untuk mengukur kuesioner adalah validitas isi (content validity). Content validity merupakan salah satu konsep pengukuran validitas dimana suatu instrumen dinilai memiliki content validity jika mengandung butir-butir pernyataan yang memadai dan representatif untuk mengukur construct sesuai dengan yang diinginkan peneliti. Pengujian menggunakan uji dua sisi dengan taraf signifikasi 0,05 dengan kriteria jika $r_{\text {hitung }}>r_{\text {tabel }}$ maka item-item pernyataan yang terdapat dalam instrument berkorelasi signifikan terhadap skor total, maka instrumen atau item-item pertanyaan dikatakan valid. Jika $r_{\text {hitung }}<r_{\text {tabel }}$ maka item-item pernyataan yang terdapat dalam instrumen tidak berkorelasi signifikan terhadap skor total, maka instrumen atau item-item pernyataan dikatakan tidak valid (Rosadi, 2016).

2. Uji Reliabilitas

Reliabilitas alat penelitian adalah ketepatan atau keajekan alat tersebut dalam menilai apa yang dinilainya. Artinya kapanpun alat penilaian tersebut akan digunakan akan memberikan hasil relatif yang sama (Taniredja \& Mustafidah, 2014:135). Instrumen dipercaya jika jawaban dari responden atas pernyataan adalah konsisten atau stabil dari waktu kewaktu. Uji ini dilakukan dengan metode cronbach alpha. Cara untuk mengukur reliabilitas dengan Cronbach Alpha dengankriteria lebih dari 0,7 reliabel (Ghozali, 2013).

\subsubsection{Uji Asumsi Klasik}

1. Uji Normalitas

Uji ini dilakukan guna mengetahui apakah nilai residu (perbedaan yang ada) yang diteliti memiliki distribusi normal atau tidak normal. Nilai residu yang berdistribusi kalau digambarkan akan beberbentuk lonceng (Wibowo, 2012:61).

Uji normalitas dapat dilakukan dengan menggunakan Kolmogorov Smirnov yang menggunakan kriteria uji normalitas dengan melihat nilai signifikansi (Sig.) dari hasil uji tersebut. Data akan berdistribusi normal apabila Sig $>0,05$.

2. Uji Multikolonieritas

Uji Multikolonieritas bertujuan untuk menguji apakah model regresi dikemukakan adanya korelasi antara variabel bebas (Independen) (Ghozali, 2013). Dengan menghitung nilai tolerance dan Variance Factor (VIF). Persamaan regresi baru dapat digunakan jika terjadi linear dari masing-masing variabel bebas. Suatu regresi dikatakan terdeteksi multikolonieritas apabila nilai Variance Inflantion Factor (VIF) menjauhi 1 (satu) atau angka tolerance menjauhi 1 (satu) pada Output coefficient. Untuk menguji adanya multikolinearitas dapat dilakukan dengan melihat nilai Variance inflationFactor (VIF). Apabila nilai (VIF) diatas 10, maka dikatakan terjadi multikolinieritas dan sebaliknya apabila nilai VIF $<10$ maka dikatakan tidak terjadi multikolinieritas. 
3. Uji Heteroskedastisitas

Uji Heteroskedastisitas bertujuan menguji apakah model regresi terjadi ketidaksamaan varians dari residual atau pengamatan ke pengamatan lain. Jika varians dari residual suatu pengamatan ke pengamatan lain tetap disebut homokedastisitas, sedangkan untuk varians yang berbeda disebut heteroskedastisitas (Ghozali, 2013). Untuk memenuhi asumsi heteroskedastisitas, maka perlu diuji apakah ada gejala heteroskedastisitas atau tidak. Dalam penelitian ini, pengujian akan dilakukan dengan dilihat melalui uji glejser.Apabila sig $\geq 0,05$ maka tidak terjadi gejala heteroskedastisitas.

\subsection{Definisi dan Pengukuran Variabel}

\subsubsection{Variabel Bebas}

Menurut Sugiyono (2016:64) variabel bebas adalah variabel yang mempengaruhi atau yang menjadi sebab perubahannya atau timbulnya variabel dependen. Variabel bebas atau independen dalam penelitian ini adalah tekanan waktu $\left(\mathrm{X}_{1}\right)$, Independensi $\left(\mathrm{X}_{2}\right)$ dan Etika $\left(\mathrm{X}_{3}\right)$.

1. Tekanan Waktu $\left(\mathrm{X}_{1}\right)$

Tekanan waktu adalah kendala yang terjadi pada perikatan audit karena keterbatasan sumber daya berupa waktu yang dialokasikan untuk melaksanakan seluruh tugas audit (Yoga, 2013:24).

Variabel ini diukur dengan 10 pernyataan dalam bentuk kuesioner (Melisa, 2012). Indikator dalam penelitian ini adalah :

a) Pemanfaatan waktu

b) Efektivitas waktu audit

2. Independensi $\left(\mathrm{X}_{2}\right)$

Independensi adalah sikap mental seorang auditor dimana ia dituntut untuk bersikap jujur dan tidak memihak sepanjang pelaksanaan audit dan dalam memposisikan dirinya dengan auditee-nya.

Variabel ini diukur dengan 7 pernyataan dalam bentuk kuesioner (Melisa, 2012). Indikator dalam penelitian ini adalah :

a) Hubungan dengan klien

b) Tekanan dari klien

c) Independensi

\section{Etika $\left(\mathrm{X}_{3}\right)$}

Etika adalah suatu prinsip moral dan perbuatan yang menjadi landasan bertindaknya seseorang sehingga apa yang dilakukannya dipandang oleh masyarakat sebagai perbuatan yang terpuji dan meningkatkan martabat dan kehormatan seseorang.

Variabel ini diukur dengan 11 pernyataan dalam bentuk kuesioner ( Putra, 2102). Indikator dalam penelitian adalah :
a) Tanggung jawab
b) Integritas
c) Objektivitas

\subsubsection{Variabel Terikat}

Varibel terikat adalah variabel yang dipengaruhi atau yang menjadi akibat, karena adanya variabel bebas (Sugiyono, 2016:64). Variabel dependen dalam penelitian adalah Kualitas Audit (Y). Kualitas audit adalah probabilitas dimana seorang auditor menemukan dan melaporkan tentang adanya suatu pelanggaran dalam sistem akuntansi klien.

Varibel ini diukur dengan 10 pernyataan dalam bentuk kuesoioner (Putra, 2012). Indikator dalam penelitian ini adalah : 

a) Probabilitas
b) Transparan

\section{HASILPENELITIAN DAN PEMBAHASAN}

\subsection{Hasil Penelitian}

\subsubsection{Deskriptif Data Responden}

1. Deskriptif Berdasarkan Jenis Kelamin Auditor

Deskripsi berdasarkan jenis kelamin auditor dapat dilihat pada table berikut :

Tabel 4.1 : Jenis Kelamin

\begin{tabular}{|l|l|l|}
\hline Jenis Kelamin & Frekuensi & Presentasi (\%) \\
\hline Laki-Laki & 25 & 71,42 \\
\hline Perempuan & 10 & 28,57 \\
\hline Jumlah & 35 & 100 \\
\hline
\end{tabular}

Pada tabel 4.1 dapat dilihat bahwa jumlah responden jenis kelamin terbanyak pada laki-laki berjumlah 25 orang atau 71,42\%, sedangkan sisanya 10 orang atau 28,57 dipenuhi oleh jenis kelamin perempuan. Artinya, sebagian besar responden yang mengisi kuesioner adalah laki-laki.

2. Deskripsi Berdasarkan Umur Auditor

Deskripsi responden berdasarkan umur auditor dapat dilihat pada tabel berikut:

Tabel 4.2 : Umur

\begin{tabular}{|l|l|l|}
\hline Usia & Frekuensi & Presentaase (\%) \\
\hline 20-30 Tahun & 9 & 25,71 \\
\hline $31-45$ Tahun & 20 & 57,14 \\
\hline 46-55 Tahun & 4 & 11,42 \\
\hline Lebih dari 55 Tahun & 2 & 5,71 \\
\hline Jumlah & 35 & 100 \\
\hline
\end{tabular}

Pada tabel 4.2 dapat dilihat bahwa jumlah responden berdasarkan usia terbesar berada pada responden berusia 31-45 sebanyak 20 orang atau 57,14\%. Responden yang berusia 2030 tahun sebanyak 9 orang atau $25,71 \%$. Kemudian responden yang berusia 46-55 tahun sebanyak 4 orang atau 11,42\%. Sedangkan responden yang berusia lebih dari 55 tahun sebanyak 2 orang atau $5,71 \%$.

3. Deskripsi Responden Berdasarkan Tingkat Pendidikan Auditor

Tabel 4.3 : Tingkat Pendidikan

\begin{tabular}{|l|l|l|}
\hline Tingkat Pendidikan & Frekuensi & Presentase (\%) \\
\hline SLTA & 3 & 8,57 \\
\hline D3 & 7 & 20 \\
\hline S1 & 20 & 57,14 \\
\hline S2 & 5 & 14,28 \\
\hline S3 & 0 & 0 \\
\hline Jumlah & 35 & 100 \\
\hline
\end{tabular}

Dari tabel 4.3 dapat dilihat jumlah responden berdasarkan tingkat pendidikan terbesar berada pada responden S1 sebanyak 20 orang atau 57,14\%, responden yang tingkat pendidikan SLTA sebanyak 3 orang atau $8,57 \%$, responden yang tingkat pendidikan D3 sebanyak 7 orang atau $20 \%$, kemudian responden yang tingkat pendidikan S2 sebanyak 5 orang atau 14,28\%. Dari 35 responden. Sedangkan responden yang tingkat pendidikan S3 tidak ada $(0 \%)$. 


\subsection{Uji Kualitas Data}

1. Uji Validitas

Tabel 4.4 : Hasil Uji Validitas Tekanan Waktu $\left(\mathrm{X}_{1}\right)$

\begin{tabular}{|l|l|l|l|}
\hline Item Pernyataan & $\mathbf{r}_{\text {hitung }}$ & $\mathbf{r}_{\text {tabel }}$ & Keterangan \\
\hline 1 & 0,613 & 0,334 & Valid \\
\hline 2 & 0,661 & 0,334 & Valid \\
\hline 3 & 0,454 & 0,334 & Valid \\
\hline 4 & 0,583 & 0,334 & Valid \\
\hline 5 & 0,782 & 0,334 & Valid \\
\hline 6 & 0,604 & 0,334 & Valid \\
\hline
\end{tabular}

Berdasarkan tabel 4.4 menunjukkan hasil yang baik dengan nilai $\mathrm{N}=35$, taraf signifikan 0,05 dan nilai $r_{\text {tabel }}$ 0,334. Pada tabel ini menunjukkan bahwa variabel tekanan waktu valid karena $r_{\text {hitung }} \geq r_{\text {tabel }}$.

Tabel 4.5 : Hasil Uji Validitas Independensi $\left(X_{2}\right)$

\begin{tabular}{|l|l|l|l|}
\hline Item Pernyataan & $\mathbf{r}_{\text {hitung }}$ & $\mathbf{r}_{\text {tabel }}$ & Keterangan \\
\hline 1 & 0,561 & 0,334 & Valid \\
\hline 2 & 0,503 & 0,334 & Valid \\
\hline 3 & 0,725 & 0,334 & Valid \\
\hline 4 & 0,473 & 0,334 & Valid \\
\hline 5 & 0,403 & 0,334 & Valid \\
\hline 6 & 0,669 & 0,334 & Valid \\
\hline 7 & 0,749 & 0,334 & Vali \\
\hline
\end{tabular}

Dari tabel 4.5 dapat dilihat bahwa $r_{\text {hitung }} \geq r_{\text {tabel }}$ itu artinya variabel inpendensi valid dan bisa digunakan dalam penelitian.

Selanjutnya uji validitas untuk variabel etika dapat dilihat pada tabel 4.6 berikut ini :

Tabel 4.6 : Hasil UJi Validitas Etika $\left(X_{3}\right)$

\begin{tabular}{|l|l|l|l|}
\hline Item Pernyataan & $\mathbf{r}_{\text {hitung }}$ & $\mathbf{r}_{\text {tabel }}$ & Keterangan \\
\hline 1 & 0,700 & 0,334 & Valid \\
\hline 2 & 0,779 & 0,334 & Valid \\
\hline 3 & 0,721 & 0,334 & Valid \\
\hline 4 & 0,816 & 0,334 & Valid \\
\hline 5 & 0,822 & 0,334 & Valid \\
\hline 6 & 0,835 & 0,334 & Valid \\
\hline 7 & 0,805 & 0,334 & Valid \\
\hline 8 & 0,760 & 0,334 & Valid \\
\hline 9 & 0,808 & 0,334 & Valid \\
\hline 10 & 0,346 & 0,334 & Valid \\
\hline 11 & 0,857 & 0,334 & Valid \\
\hline
\end{tabular}


Hasil uji validitas pada tabel 4.6 menunjukkan bahwa variabel etika $r_{\text {hitung }} \geq r_{\text {tabel }}$ itu artinya valid dan pernyataan pada variabel etika bisa digunakan dalam penelitian.

Tabel 4.7 Uji Validitas Kualitas Audit (Y)

\begin{tabular}{|l|l|l|l|}
\hline Item Pernyataan & $\mathbf{r}_{\text {hitung }}$ & $\mathbf{r}_{\text {tabel }}$ & Keterangan \\
\hline 1 & 0,891 & 0,334 & Valid \\
\hline 2 & 0,909 & 0,334 & Valid \\
\hline 3 & 0,940 & 0,334 & Valid \\
\hline 4 & 0,894 & 0,334 & Valid \\
\hline 5 & 0,814 & 0,334 & Valid \\
\hline 6 & 0,878 & 0,334 & Valid \\
\hline 7 & 0,936 & 0,334 & Valid \\
\hline 8 & 0,864 & 0,334 & Valid \\
\hline 9 & 0,923 & 0,334 & Valid \\
\hline 10 & 0,639 & 0,334 & Valid \\
\hline
\end{tabular}

Berdasarkan hasil perhitungan SPSS 17 pada tabel 4.7 menunjukkan hasil yang baik dengan nilai $\mathrm{N}=35$, taraf signifikan 0,05 dan nilai $r_{\text {tabel }}$ 0,334. Tabel tersebut menunjukkan bahwa pernyataan dari variabel kualitas audit adalah valid karena $r_{\text {hitung }} \geq r_{\text {tabel }}$.

\section{Uji Reliabilitas}

Tabel 4.8 : Hasil Uji Reliabilitas Tekanan Waktu

\begin{tabular}{|l|l|}
\hline $\begin{array}{l}\text { Cronbach's } \\
\text { Alpha }\end{array}$ & N of Items \\
\hline 653 & 6 \\
\hline
\end{tabular}

Hasil uji reliablitas menunjukkan Cronbach's alpha sebesar 0,653 dan dinyatakan reliabel karena nilainya lebih besar dari $0,60(0,653 \geq 0,60)$.

Selanjutnya uji reliabilitas untuk variabel independensi dapat dilihat pada tabel 4.9 berikut ini :

\section{Tabel 4.9 : Hasil Uji Reliabilitas Independensi}

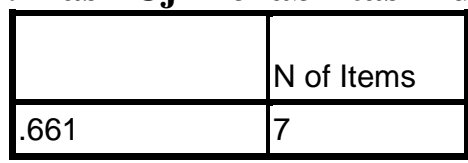

Hasil uji reliabilitas menunjukkan Cronbach's alpha 0,661 dan dinyatakan reliabel karena nilainya lebih besar dari $0,60(0,661 \geq 0,60)$.

Selanjutnya uji reliabilitas untuk variabel etika dapat dilihat pada tabel 4.10 berikut ini :

\section{Tabel 4.10 Uji Reliabilitas Etika}

\begin{tabular}{|l|l|}
\hline $\begin{array}{l}\text { Cronbach's } \\
\text { Alpha }\end{array}$ & N of Items \\
\hline .912 & 11 \\
\hline
\end{tabular}

Hasil uji reliabilitas menunjukkanCronbach's alpha 0,912 dan dinyatakan reliabel karena nilainya lebih besar dari $0,60(0,912 \geq 0,60)$.

Selanjutnya uji reliabilitas untuk variabel kualitas audit dapat dilihat pada tabel 4.11 berikut ini :

\section{Tabel 4.11 Uji Reliabilitas Kualitas Audit}

\begin{tabular}{|l|l|}
\hline $\begin{array}{l}\text { Cronbach's } \\
\text { Alpha }\end{array}$ & N of Items \\
\hline .962 & 10 \\
\hline
\end{tabular}


Hasil uji reliabilitas menunjukkan Cronbach's alpha 0,962 dan dinyatakan reliabel karena nilainya lebi besar dari 0,60 $(0,962 \geq 0,60)$.

\subsection{Uji Asumsi Klasik.}

\section{Uji Normalitas}

Tabel 4.12 : Tabel Uji Normalitas

One-Sample Kolmogorov-Smirnov Test

\begin{tabular}{|ll|l|}
\hline & & $\begin{array}{l}\text { Unstandardized } \\
\text { Residual }\end{array}$ \\
\hline$N$ & 35 \\
Normal $\quad$ Mean & .0000000 \\
Parameters ${ }^{\mathrm{a}, \mathrm{b}}$ & Std. Deviation & 2.90972039 \\
Most Extreme & Absolute & .065 \\
Differences $\quad$ Positive & .065 \\
& Negative & -.064 \\
Kolmogorov-Smirnov Z & .383 \\
Asymp. Sig. (2-tailed) & .999 \\
\hline
\end{tabular}

Hasil uji normalitas dengan menggunakan uji kolmogorof-sminoy adalah dengan melihat nilai kormogorof-sminoy dan signifikan dari data yang telah diolah.Dari tabel 4.12 diatas dapat dilihat bahwa besarnya nilai kolmogorof-sminoy adalah 0,383 dan signifikan pada 0,999 . Hal ini berarti data residual terdistribusi secara normal karena signifikannya berada diatas 0,05 atau $5 \%$. 


\section{Normal P-P Plot of Regression Standardized Residual}

\section{Dependent Variable: Kualitas_audit}

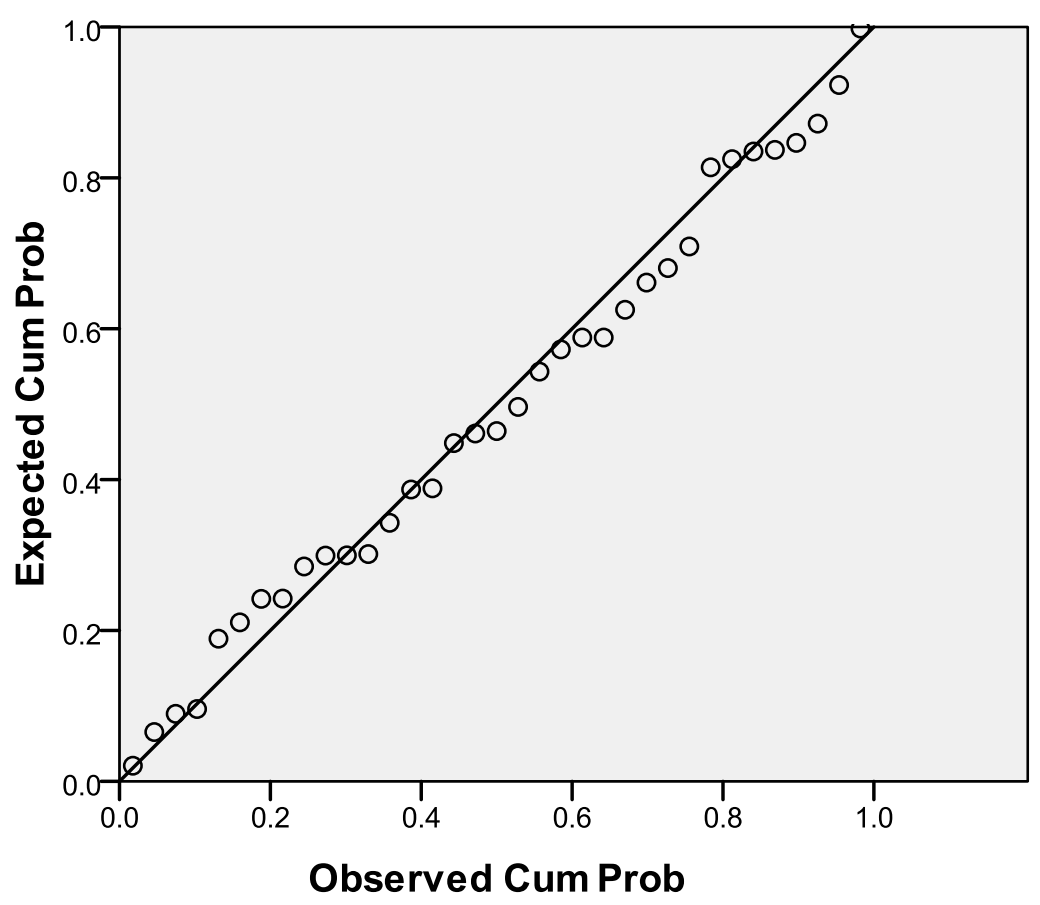

\section{Gambar 4.1 Hasil Uji Normalitas}

Berdasarkan garafik 4.1 dapat dilihat bahwa titik yang menyebar disekitar garis dan mengikuti garis diagonal.Oleh karena itu model regresi memenuhi asumsi normalitas.

\section{Uji Multikolonieritas}

Tabel 4.13 : Hasil Uji Multikolonieritas

\begin{tabular}{|l|l|l|}
\hline Variabel & Tolerance & VIF \\
\hline Independensi & 0,587 & 1,703 \\
\hline Etika & 0,436 & 2,291 \\
\hline Kualitas Audit & 0,550 & 1,819 \\
\hline
\end{tabular}

Dari tabel 4.13 dapat dilihat bahwa nilai tolerance dari variabel independen lebih dari 0,1 dan nilai VIF kurang dari 10. Hal ini menunjukan tidak terjadi multikolonieritas. 


\section{Uji Heteroskedastisitas}

Tabel 4.14 Hasil Uji Heteroskedastisitas

\begin{tabular}{|c|c|c|c|c|c|c|}
\hline \multirow{2}{*}{\multicolumn{2}{|c|}{ Model }} & \multicolumn{2}{|c|}{ Unstandardized Coefficients } & \multirow{2}{*}{\begin{tabular}{|l} 
Standardized \\
Coefficients \\
Beta \\
\end{tabular}} & \multirow[b]{2}{*}{$\mathrm{T}$} & \multirow[b]{2}{*}{ Sig. } \\
\hline & & $B$ & Std. Error & & & \\
\hline \multirow[t]{4}{*}{1} & (Constant) & 2.057 & 3.013 & & .683 & .500 \\
\hline & TEKANAN_WAKTU & -.070 & .127 & -.102 & -.547 & .588 \\
\hline & INDEPENDENSI & -.149 & .146 & -.221 & -1.018 & .317 \\
\hline & ETIKA & .115 & .088 & .284 & 1.304 & .202 \\
\hline
\end{tabular}

a. Dependent Variable: RES2

Berdasarkan tabel 4.14 diatas diketahui bahwa nilai signifikan variabel tekanan waktu $\left(\mathrm{X}_{1}\right)$ sebesar 0,588 lebih besar dari 0,05, artinya tidak terjadi heteroskedastisitas pada variabel tekanan waktu. Sementara itu, nilai signifikan pada variabel independensi $\left(\mathrm{X}_{2}\right)$ yaitu 0,317 , artinya variabel independensi tidak terjadi heteroskedastisitas. Kemudian diketahui nilai signifikan variabel etika $\left(X_{3}\right)$ sebesar 0,202 itu artinya variabel etika tidak terjadi heteroskedastisitas karena nilai signifikannya lebih besar dari 0,05.

\subsection{Uji Regresi Linear Berganda}

Coefficients $^{a}$

Tabel 4.14 Hasil Uji t Tet

\begin{tabular}{|c|c|c|c|c|c|c|}
\hline \multirow{2}{*}{\multicolumn{2}{|c|}{ Model }} & \multicolumn{2}{|c|}{ Unstandardized Coefficients } & \multirow{2}{*}{\begin{tabular}{|l|} 
Standardized \\
Coefficients \\
Beta \\
\end{tabular}} & \multirow[b]{2}{*}{$\mathrm{T}$} & \multirow[b]{2}{*}{ Sig. } \\
\hline & & $\mathrm{B}$ & Std. Error & & & \\
\hline \multirow[t]{4}{*}{1} & (Constant) & 2.765 & 4.946 & & .559 & .580 \\
\hline & Tekanan_waktu & .103 & .209 & .062 & .409 & .507 \\
\hline & Independensi & .122 & .244 & .077 & .501 & .620 \\
\hline & Etika & .493 & .154 & .498 & 3.200 & .003 \\
\hline
\end{tabular}

a. Dependent Variable: Kualitas_audit

Berdasarkan tabel koefisien diatas, pada kolom unstanddardized coefficients bagian $\mathrm{B}$ diperoleh model permasalahan regresi linear berganda sebagai berikut :

$$
\mathrm{Y}=2,765+0,103\left(\mathrm{X}_{1}\right)+0,122\left(\mathrm{X}_{2}\right)+0,493\left(\mathrm{X}_{3}\right)+\mathrm{e}
$$

\subsubsection{Uji Hipotesis}

Berdasarkan tabel 4.14 , nilai sig untuk pengaruh tekanan waktu $\left(\mathrm{X}_{1}\right)$ terhadap $\mathrm{Y}$ adalah sebesar $(0,507 \geq 0,05)$ dan nilai thitung lebih kecil dari t tabel $(0,409 \leq 2,035)$, sehingga dapat disimpulkan bahwa $\mathrm{H}_{1}$ ditolak dan $\mathrm{H}_{0}$ diterima yang berarti tidak terdapat pengaruh $\mathrm{X}_{1}$ terhadap Y.

Nilai sig untuk independensi $\left(\mathrm{X}_{2}\right)$ terhadap $\mathrm{Y}$ adalah sebesar $(0,620 \geq 0,05)$ dan nilai $\mathrm{t}$ hitung lebih kecil dari dari $\mathrm{t}$ tabel $(0,501 \leq 2,035)$, sehingga dapat disimpulkan bahwa $\mathrm{H}_{2}$ ditolak dan $\mathrm{H}_{0}$ diterima yang berarti tidak terdapat pengaruh $\mathrm{X}_{2}$ terhadap $\mathrm{Y}$.

Nilai sig untuk etika $\left(\mathrm{X}_{3}\right)$ terhadap $\mathrm{Y}$ adalah sebesar $(0,003 \leq 0,05)$ dan $\mathrm{t}$ hitung $(3,200 \geq 2,035)$, sehingga dapat disimpulkan bahwa $\mathrm{H}_{3}$ diterima dan $\mathrm{H}_{0}$ ditolak yang berarti terdapat pengaruh $\mathrm{X}_{3}$ terhadap $\mathrm{Y}$.

\subsection{Pembahasan Hasil Penelitian}

\subsubsection{Pengaruh Tekanan Waktu Terhadap Kualitas Audit}

Berdasarkan hasil uji t menunjukkan bahwa tekanan waktu tidak berpengaruh signifikan terhadap kualitas audit, ini mengartikan bahwa auditor dalam melakukan audit 
meskipun adanya penekanan waktu atau pengurangan waktu tidak ada pengaruhnya terhadap kualitas audit. Tidak berpengaruhnya tekanan waktu terhadap kualitas audit menunjukkan bahwa Kantor Inspektorat Kabupaten Kepulauan Sangihe sangat menjaga reputasi atau nama perusahaan.

Hasil penelitian ini mendukung penelitian yang dilakukan oleh (Rustiarini, 2013, Noviansyah, 2016, Putri, 2013) yang menyatakan bahwa dalam melakukan suatu penugasan seorang auditor sudah memiliki alokasi waktu yang disesuaikan dengan kompleksitas tugas yang diberikan sehingga auditor harus melaksanakan tugas yang diberikan secara efisien.

\subsubsection{Pengaruh Independensi Terhadap Kualias Audit}

Setelah dilakukan pengujian didapatkan bahwa independensi tidak berpengaruh signifikan terhadap kualitas audit. Karena yang saya teliti adalah Kantor Inspektorat Kabupaten Kepulauan Sangihe itu adalah audit internal, jadi auditor yang bekerja di Kantor Inspektorat Kabupaten Kepulauan Sangihe masih dipengaruhi oleh atasan atau pimpinan.

Penelitian ini sejalan dengan penelitian yang dilakukan oleh Tjun, dkk. (2014) dimana hasil penelitian tersebut bahwa independensi tidak memiliki pengaruh signifikan terhadap kualitas audit. Faktor yang menyebabkan independensi tidak memiliki pengaruh terhadap kualitas audit adalah karena pelanggaran yang dilakukan auditor terhadap sikap independen yang dimiliki.

\subsubsection{Pengaruh Etika Terhadap Kualitas Audit}

Setelah dilakukan pengujian didapatkan hasil bahwa etika berpengaruh terhadap kualitas audit pada Kantor Inspektorat Kabupaten Kepulauan Sangihe.Hal ini menunjukkan bahwa semakin tinggi etika auditor maka semakin baik pula kualitas audit pada Kantor Inspektorat Kabupaten Kepulauan Sangihe.

Hasil penelitian ini mendukung (Rahma, 2012, Suputra, 2103) yang menyatakan etika berpengaruh terhadap kualitas audit. Dengan menjunjung tinggi etika diharapkan tidak terjadi kecurangan diantara para auditor, sehingga dapat memberikan pendapat audit yang benarbenar sesuai dengan laporan keuangan yang disajikan.

\subsection{Kesimpulan}

Berdasarkan hasil penelitian yang telah diuraikan sebelumnya, maka dapat diambil kesimpulan sebagai berikut:

1. Tekanan waktu dalam melaksanakan audit tidak berpengaruh terhadap kualitas audit pada Kantor Inspektorat Kabupaten Kepulauan Sangihe. Hal ini dilihat dari nilai t hitung lebih kecil dari pada nilai t tabel $(0,409 \leq 2,032)$ dan nilai signifikansi yang lebi besar dari nilai signifikansi $5 \%(0,507 \geq 0,05)$, ini mengindikasikan bahwa auditor dalam melakukan audit meski adanya penekanan waktu atau pengurangan waktu tidak ada pengaruhnya terhadap kualitas audit.

2. Independensi dalam melaksanakan audit tidak berpengaruh terhadap kualitas audit. Hal ini ditunjukkan dari nilai $t$ hitung lebih kecil daripada nilai $t$ tabel $(0,501 \leq 2,032)$ dan nilai signifikansi yang lebih kecil daripada nilai signifikansi $5 \%(0,620 \geq 0,05)$.

3. Etika berpengaruh terhadap kualitas audit. Hal ini ditunjukkan nilai t hitung lebih besar daripada nilai t tabel $(3,200 \geq 2,032)$ dan nilai signifikansi yang lebih besar daripada nilai signifikansi $5 \% \quad(0,003 \leq 0,05)$. Karena semakin tinggi etika auditor akan menghasilkan kualitas audit yang baik.

\subsection{Saran}

Berdasarkan hasil penelitian yang telah dilakukan maka diajukan saran, antara lain : 
1. Hasil penelitian menunjukkan bahwa tekanan waktu tidak berpengaruh terhadap kualitas audit. Hasil itu juga berimplikasi pada pola penugasan auditor, dimana perlu membuat sebuah taksiran kebutuhan waktu audit sebagai bagian dari pertimbangan penjadwalan sehingga auditor dapat melaksanakan proses audit dengan waktu yang telah ditetapkan agar tidak menyebabkan perilaku yang menurunkan kualitas audit.

2. Untuk para auditor diharapkan lebih meningkatkan independensi. Agar auditor yang mendapatkan tugas dari klien diharapkan benar-benar melaksakan tugasnya dengan baik, tidak mendapatkan tekanan dari klien sehingga dalam melaksanakan tugas auditnya secara objektif dan dapat menghasilkan audit yang berkualitas.

3. Bagi para auditor diharapkan lebih meningkatkan etika, karena etika mempunyai pengaruh terhadap kualitas audit. Hal ini menunjukan bahwa seorang auditor harus mempunyai etika yang baik dalam menjalankan tanggungjawabnya.

4. Untuk penelitian selanjutnya hendaknya dapat mempertimbangkan untuk menambah variabel lain yang dapat mempengaruhi kualitas audit.

\section{DAFTAR PUSTAKA}

Amalia, Sabrina Rahutami Nur. 2014. Pengaruh Auditor Internal Terhadap Kualitas Audit Pelaporan Keuangan Pada Bank Perkreditan Rakyat Di Jawa Tengah. Fakultas Ekonomi Dan Bisnis Universitas Diponegoro.

Atmawinata, Susilawati Maya. 2014. Pengaruh Profesionalisme Dan Independensi Auditor Internal Terhadap Kualitas Audit Studi Pada Kantor Inspektorat Propinsi Jawa Barat.STIE STEMBI, Vol 13 No 2, Oktober 2014.

Agneus Sintya, 2016. Pengaruh Kompetensi, Independensi, dan Tekanan Anggaran Waktu Terhadap Kualitas Audit. Fakultas Ekonomi dan Bisnis Universitas Trisakti.

Al-Khaddash Husam, et,al. 2013. Factors Affecting The Quality oh Auditing ; The Case of Jourdanian Comercial Bank. International Journal of Business and Social Science American University of The Middle East. International Journal of Bussines and Social Science, Vol. 4 No. 11 ; September 2013.

Bustami Arif, 2013. Pengaru Independensi, Akuntabilitas dan Profesionalisme Auditor Terhadap Kualitas Audit. ( Studi Empiris pada Kantor Akuntan Publik di DKI Jakarta).

Budiartha, Ketut. 2015. Pengaruh Independensi, Pengalaman Kerja, Due Professional Care, Dan Akuntabilitas Terhadap Kualitas Audit. Fakultas Ekonomi Udayana (Unud), Bali, Indonesia. Jurnal Akuntansi Vol 10 No.Januari 2015.

Deddi Nordiawan, Iswahyudi Sondi Putra, dan Maulidah Rahmawati.Jakarta.Penerbit Salemba Empat.

Dutadasanovan, Yoga. 2013. Pengaruh Time Budget Pressure Terhadap Kualitas Audit Dengan Independensi Sebagai Variabel Intervening.Universitas Negeri Semarang.

Futri Putu Septiani, Juliarsa Gede. 2014. Pengaruh Independensi, Profesionalisme, Tingkat Pendidika, Etika Profesi, Pengalaman Dan Kepuasan Kerja Auditor Pada Kualitas Audit Kantor Akuntan Publik Di Bali. Fakultas Ekonomi Dan Bisnis Udayana (Unud), Bali, Indonesia. Vol 7 No. 2 Mei 2014.

Fonda, Ausella Jean. 2014. Pengaruh Tekanan Anggaran Waktu, Tipe Kepribadian Auditor, Independensi, dan Kompetensi Terhadap Kualitas Audit (Studi Empiris Pada Auditor KAP Di Semarang).Skripsi.Fakultas Ekonomika dan Bisnis Universitas Diponegoro.

Ghozali,Iman. 2013. Aplikasi Analisis Program Multivariad dengan Program IBM. SPSS.21.

Edisi 7. Semarang, Penerbit Universitas Diponegoro.

Halim Abdul, 2008. Akuntansi Sektor Publik Edisi Dua. Jakarta. Penerbit Salemba Empat. Halim Abdul, 2015. Auditing. Yogyakarta, Penerbit Sekolah Tinggi Ilmu Manajemen YKPN. 